\title{
Rhythmic growth fluctuations in forest trees of Central Europe and the Front Range in Colorado
}

\author{
Fritz Hans Schweingruber ${ }^{1}$, Käthi Aellen-Rumo ${ }^{2}$, Urs Weber ${ }^{3}$, and Urs Wehrli ${ }^{2}$ \\ ${ }^{1}$ Swiss Federal Institute for Forest, Snow and Landscape Research, CH-8903 Birmensdorf, Switzerland \\ 2 Institute of Botany, University of Basel, Schönbeinstrasse 6, CH-4056 Basel, Switzerland \\ ${ }^{3}$ Swiss National Museum, CH-8001 Zurich, Switzerland
}

Received 8 September 1989/12 March 1990

Summary. Growth ring sequences in conifers and broadleaved trees show abrupt growth reductions persisting for several years. The frequency and duration of such reductions in almost 10000 trees in forest stands of Central Europe, in particular Switzerland, and in the Front Range, Colorado, USA, is related to species, climate and weather, and geographical unit. The growth reductions in the populations investigated are concentrated in certain periods and, in all species examined, essentially related to periods of drought in the spring and summer months. During the years covered by the study $(1850-1985)$, periods of growth reduction occur in Central Europe, the Front Range, Colorado, and also in the Hudson Valley, New York, at irregular intervals of 6-34 years, and on average every 13-14 years. The growth reduction periods normally do not show synchronism between the three areas investigated. Regionally valid growth periodicities can only be definitely determined through the examination of a very large amount of material comprising a number of species growing in different forest stands and on different sites within a major phytosociological unit. Findings from studies on trees in different climatic areas or on few samples scarcely allow reliable comparisons.

Key words: Dendrochronology - Abrupt growth changes - Periodicities

\section{Introduction}

Dendro-ecological studies in an area of Switzerland exposed to pollutant gases (the Valais) revealed that Scots pines often display abrupt growth reduction or recovery (Kienast et al. 1981). Subsequently numerous studies were

Offprint requests to: F. H. Schweingruber conducted in the Alps and in the Front Range, Colorado (Schweingruber et al. 1986), with the aim of dating the onset and duration of abrupt changes in growth lasting 4 or more years and relating them to the aging of the individual, species, site, stand, region, climate, climatic events, insect damage, and anthropogenic stresses. Through determining and graphically representing the single years and phases with factors strongly inhibiting or promoting growth within the life of each individual, the identity of the most ecologically influential factors acting over a period of years was sought. All normal events not visually conspicuous are omitted.

The present study concerns the frequency of growth reductions occurring in wave-like patterns. In particular, geographic synchronism is determined and the climatic factors triggering the different patterns sought.

Abrupt growth changes could be caused by alterations in the supply of water, nutrients, or light, mechanical injury of the crown or root system, or toxic physiological influences. Climatic factors inhibiting growth may result in the formation of one or two narrow growth rings (event years). Indirectly, however, the also may change the conditions of competition within the stand, placing disadvantaged in individuals in a situation of light deficiency and consequently leading to growth reductions lasting some time. Abrupt increases in growth on the other hand are often the result of increased light supply. The reason that abrupt recovery frequently follows only a slight improvement in climatic conditions has not yet been clarified.

The ability of individuals to react to an ecological event is very varied. This is particularly apparent in stands after a climatic event with a greatly limiting effect. In some individuals, no reaction is reflected in the growth ring pattern at all. In others, 1 or 2 pointer years are formed in the year of the event or the year after, while in others a growth reduction lasting several years occurs. This variation in ability to react demands the analysis of many individuals of different species and from different sites before the time and intensity of a climatic event can be definitely established. 
Table 1. The material investigated

\begin{tabular}{|c|c|c|c|}
\hline Region & Species & $\begin{array}{l}\text { Number } \\
\text { of sites }\end{array}$ & $\begin{array}{l}\text { Number } \\
\text { of trees }\end{array}$ \\
\hline \multicolumn{4}{|l|}{ Switzerland } \\
\hline \multirow[t]{3}{*}{ Valais } & Pinus sylvestris & 39 & 621 \\
\hline & Abies alba & 41 & 634 \\
\hline & Picea abies & 84 & 1327 \\
\hline \multirow{2}{*}{ Rhine Valley near Chur } & Pinus sylvestris & 30 & 494 \\
\hline & Abies alba & 22 & 500 \\
\hline \multirow[t]{2}{*}{ Canton Aargau } & Abies alba & 41 & 620 \\
\hline & Picea abies & 47 & 657 \\
\hline $\begin{array}{l}\text { Canton Aargau, } \\
\text { Bremgarten }\end{array}$ & Abies alba & 1 & 41 \\
\hline \multirow{2}{*}{ Canton Solothurn } & Abies alba & 29 & 464 \\
\hline & Picea abies & 30 & 480 \\
\hline City of Zurich & Picea abies & single trees & 100 \\
\hline \multirow[t]{3}{*}{ Liestal, Canton Basel } & Picea abies & 20 & 100 \\
\hline & Abies alba & 20 & 100 \\
\hline & Fagus sylvatica & 20 & 100 \\
\hline \multirow{5}{*}{$\begin{array}{l}\text { Canton Beme, Krauch- } \\
\text { thal, Hub }\end{array}$} & & & \\
\hline & Pinus sylvestris & 4 & 65 \\
\hline & Picea abies & 7 & 99 \\
\hline & Abies alba & 2 & 21 \\
\hline & Fagus sylvatica & 8 & 128 \\
\hline \multirow{5}{*}{$\begin{array}{l}\text { Canton Berne, Krauch- } \\
\text { thal, Dorf }\end{array}$} & & & \\
\hline & Pinus sylvestris & 3 & 48 \\
\hline & Picea abies & 4 & 64 \\
\hline & Abies alba & 2 & 32 \\
\hline & Fagus sylvatica & 7 & 112 \\
\hline \multicolumn{4}{|l|}{ Italy } \\
\hline Province of Bolzano & Picea abies & Network & 2328 \\
\hline \multirow[t]{2}{*}{ Province of Trento } & Picea abies & 20 & 311 \\
\hline & Abies alba & 13 & 199 \\
\hline \multicolumn{4}{|l|}{ USA } \\
\hline $\begin{array}{l}\text { Colorado Front Range } \\
\text { west of }\end{array}$ & Pseudotsuga menziesii & 26 & 366 \\
\hline \multirow[t]{3}{*}{ Boulder } & Picea pungens & 8 & 98 \\
\hline & Pinus ponderosa & 8 & 92 \\
\hline & Pinus contorta & 2 & 24 \\
\hline
\end{tabular}

Origin, species, number of sites and cores. Each site is a phytosociologically defined (Braun-Blanquet method) area of some $500-1000 \mathrm{~m}^{2}$ and as a rule includes 16 trees, one core being taken from each. The analysis of the first samples was completed in 1983, and that of the last in 1987

\section{Materials and methods}

The material originates from stands with differing site conditions in the topographically dissected areas of Central Europe (Alps, Mittelland, and Jura) and the Front Range in Colorado (Table 1). In all sub-areas core samples were taken from dominant and co-dominant trees from the whole range of sites able to support forest growth in the overall area. Most of the samples from Central Europe were collected in forests which have been managed for some 120 years; those stands from the Front Range were greatly influenced by ruinous exploitation between approximately 1880 and 1920 and have since remained unmanaged. The climatic-phytosociological conditions differ from sub-area to sub-area (Fig. 1). They may be characterized as follows:

Alps (Northern and Southern Alps, including the Mittelland): moistmoderate, temperate, from 400 to $1100 \mathrm{~m}$ above sea level (a. s. 1.) colline and montane zones in the range of the beech-fir belt (climatic diagram for Bern). Central Alps: dry to moderate, continental in tone, from 500 to $1200 \mathrm{~m}$ a. s. 1 , colline and montane zones in the range of the pine-fir belt (climatic diagram Sitten).

Front Range, Colorado: semi-arid and continental. 2000-2600 m a. s. 1., montane zone in the range of Pinus ponderosa and Pseudotsuga menziesii belt (climatic diagram Idaho Springs).

Abrupt growth changes were defined as a sequence of four or more rings conspicuously narrower or wider than those of the preceding period. Long-lasting abrupt changes differ from the sequences of 1-3 visually conspicuous years (event years) only in their duration (Schweingruber et al. 1986).

The beginning and end of abrupt growth changes in polished cores and stem discs were dated absolutely by means of event years (Fig. 2), with only reductions of at least $40 \%$ and increases of at least $160 \%$ in relation to the preceding rings being considered (Kontic et al. 1986; Schweingruber et al. 1986). Histograms were then constructed to show the frequency of trees with incipient growth reduction or recovery (event years) or the frequency of trees undergoing a phase of reduction or recovery in a given year. A recovery is reflected by a decrease in the frequency of reductions (Fig. 3).

The onset of reduction and recovery phases was defined by the greatest frequency of trees with such events within a given period. The maximum number of reduction phases was determined through the culmination of the frequency distribution of trees with reductions (Fig. 3). The maximum number of large-scale growth phases was found through the summation of all frequency maxima specific to localities and species in each period. Most of the findings discussed below are based on this parameter.

\section{Results}

Both European and American material display periods of growth reduction which are not specific to sites or species and which can be recognized and interpreted back to the middle of the nineteenth century. The following discussion

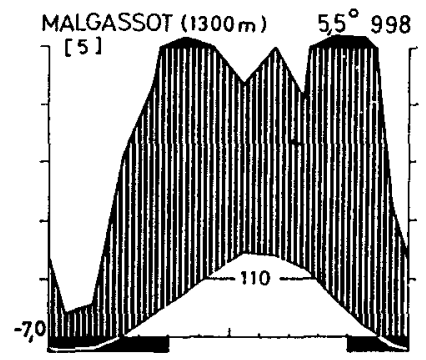

South Alps, I taly

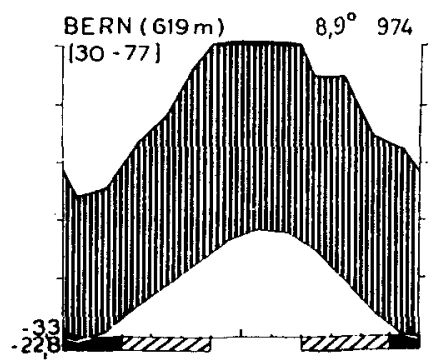

Central Plateau switzerland

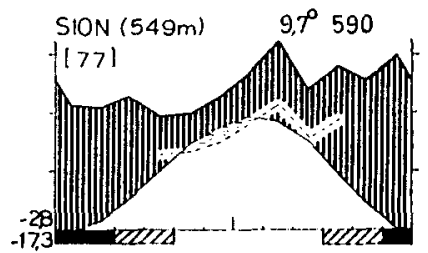

Central alpine Valley switzerland

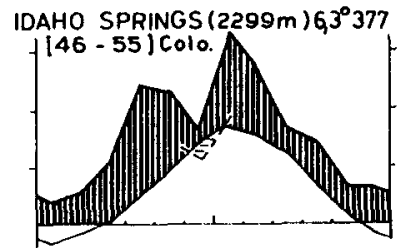

Front Range

Colorado, USA

Fig. 1. Climatic diagrams of the study areas. After Walter and Lieth (1960-1967) 


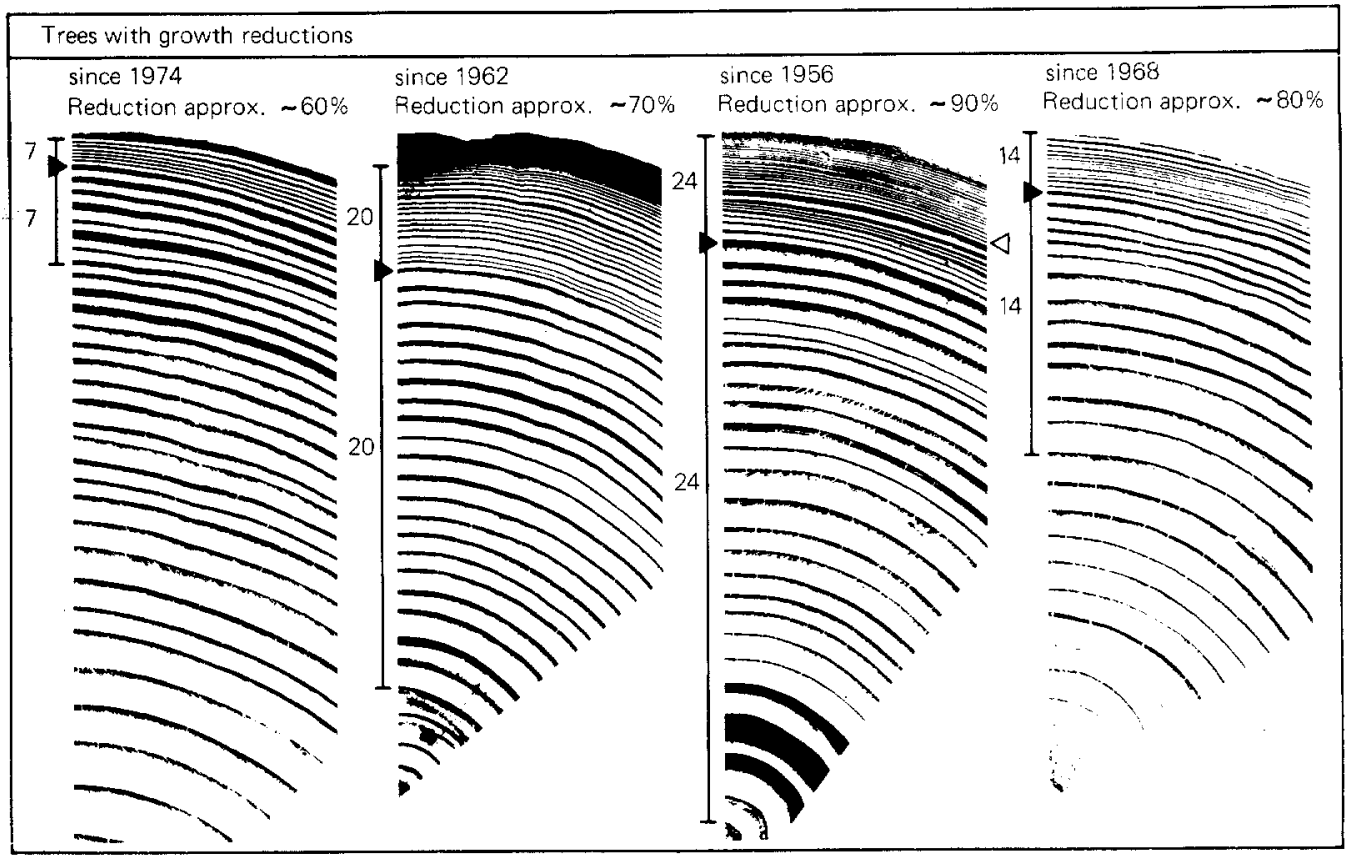

Fig. 2. Photocopies of cross-sections with abrupt growth changes

Event diagram

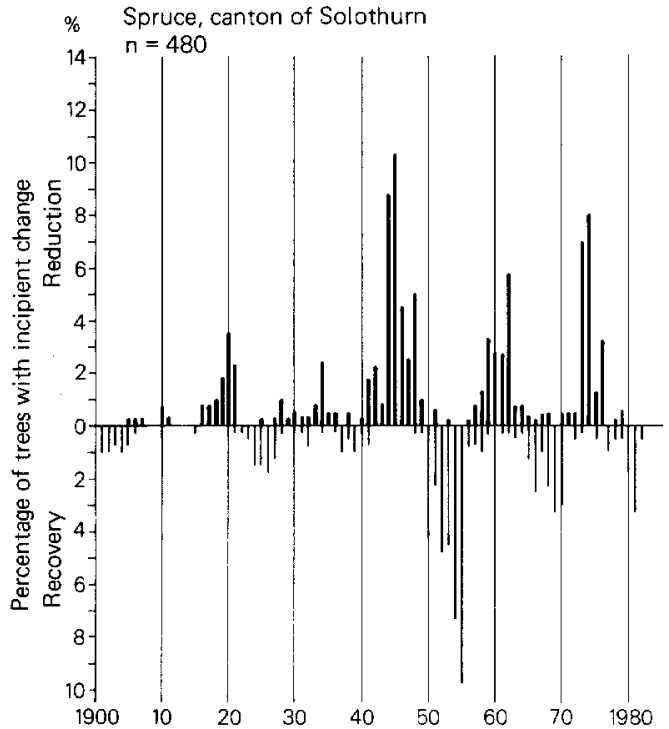

Fig. 3. Event and phase diagram for spruce (Picea abies) for the region of Solothurn, Switzerland. The event diagram shows how many trees per year underwent a reduction of $40 \%$ or more (above the centre line) or an increase of $160 \%$ or more (under the centre line). The phase diagram shows how many trees per year were undergoing a phase of reduced growth. The number of trees with a reduction of $40 \%-55 \%$ (upper line) is fairly high, those with a reduction of $56 \%-70 \%$ (centre line) medium, and those with a reduction of more than $70 \%$ (lower line over black area) low. The culmination points of the reduction phases are marked with

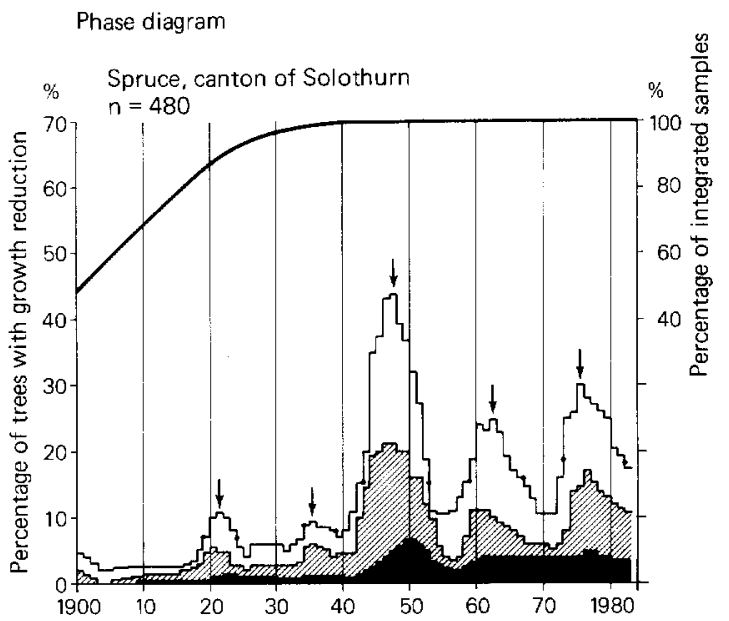

arrows. The event diagram reveals that the proportion of trees reducing their growth is high in certain years, e. g. 1920 (1934), 1944/45, 1962, and 1973/74. The phase diagram shows that at all times there are a number of trees exhibiting reduced growth. This basic proportion is affected by the age of the trees (general increase) and climatic influences (superimposed wave-like movement). The intensity of this movement is expressed by the difference between the preceding minimum and the culmination of the wave (Table 2) 


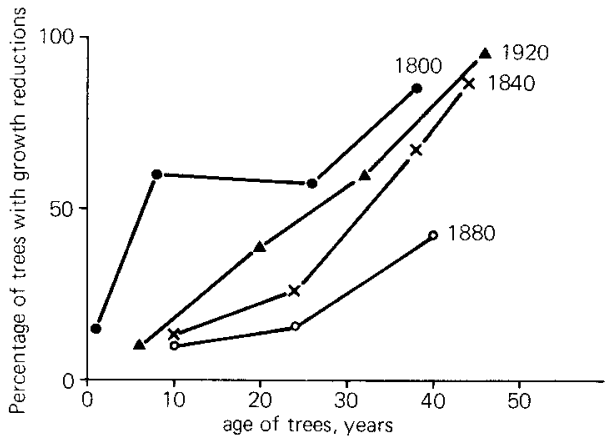

Fig. 4. Increasing frequency of trees with growth reductions in the first 50 years of life. The diagram shows the first three or four culmination points of the reduction phases in tree groups with differing germination dates $(1800,1840,1880,1920)$

Table 2. Intensity of the most recent growth reduction periods in Switzerland

\begin{tabular}{lccc}
\hline & \multicolumn{2}{c}{ Date } & \\
\cline { 2 - 4 } & 1948 & 1962 & 1976 \\
\hline Spruce & & & \\
$\quad$ Aargau & 5 & 9 & 2 \\
$\quad$ Solothurn & 30 & 15 & 20 \\
$\quad$ Valais & 5 & 8 & 10 \\
Fir & & & \\
$\quad$ Aargau & 20 & 18 & 10 \\
Solothurn & 40 & 13 & 25 \\
$\quad$ Valais & 5 & 5 & 45 \\
$\quad$ Chur & - & & 20 \\
Scots pine & 5 & 15 & 20 \\
$\quad$ Chur & 40 & 45 & 15 \\
$\quad$ Krauchthal & 10 & 4 & 40 \\
$\quad$ Valais & & & \\
\hline
\end{tabular}

The Table shows the percentage difference in the frequency of trees with growth reductions between the time of peak growth and the culmination of the reduction phase

mainly deals with the material from Central Europe, as most of the results are from this region.

Cambial age affects the intensity and frequency of abrupt growth changes. Young cambia, whether at the base of young trees or near the tip of old trees, display fewer abrupt changes in their first 50 years or so than later. From

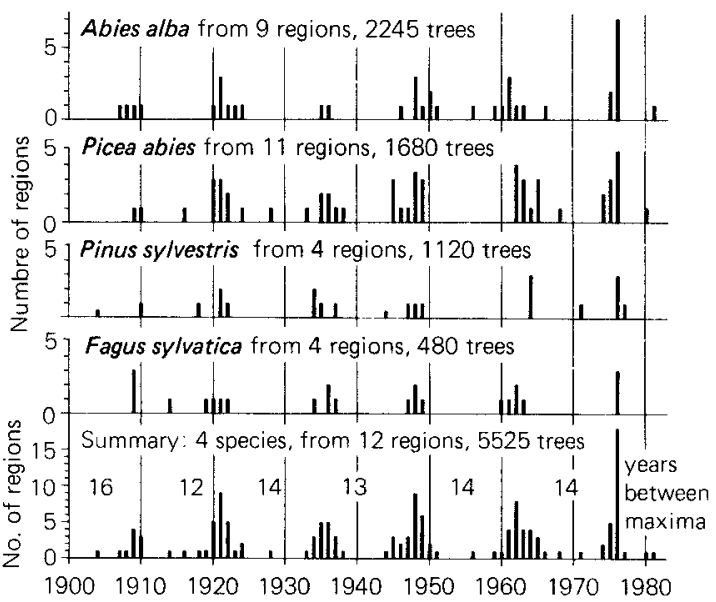

Fig. 5. Frequency of culmination points for growth reduction in phase diagrams for trees from Central Europe (Switzerland, northern Italy). The culmination points for the major tree species of Central Europe are summed for the period $1900-1983$. The summation diagram also shows the lengths of the periods (in years) between the culmination maxima. For the twentieth century, a periodicity of $12-16$ years is manifest

that time onwards, the sensitivity of trees to strong ecological influences seems hardly to change. This fact explains the trend towards more frequent growth reductions up to very recent times. Frequency distributions stratified according to tree age always show an increase in the first years of life (Fig. 4). In sample groups of 150-year-old trees, no increase in abrupt growth reductions is apparent.

The momentary intensity of ecological events is reflected in the concentration of trees with growth reductions in particular years (event years). In Switzerland, 2\%-8\% of the trees in the various sub-areas display growth reductions in 1921, 1944, 1962, 1973, 1974 and 1976. In 1951 and 1977 the cases of recovery increase. 1956 proves to be a negative event year only for firs in the Mittelland and the Jura (Schweingruber et al. 1986).

The biological persistence of ecological events is expressed in the frequency of trees whose growth is inhibited for a longer or shorter time. As a certain proportion of trees in every stand always displays reduced growth, the maximum frequency value of any phase must be related to the minimum values of the preceding and subsequent phases. The difference between the maximum and minimum

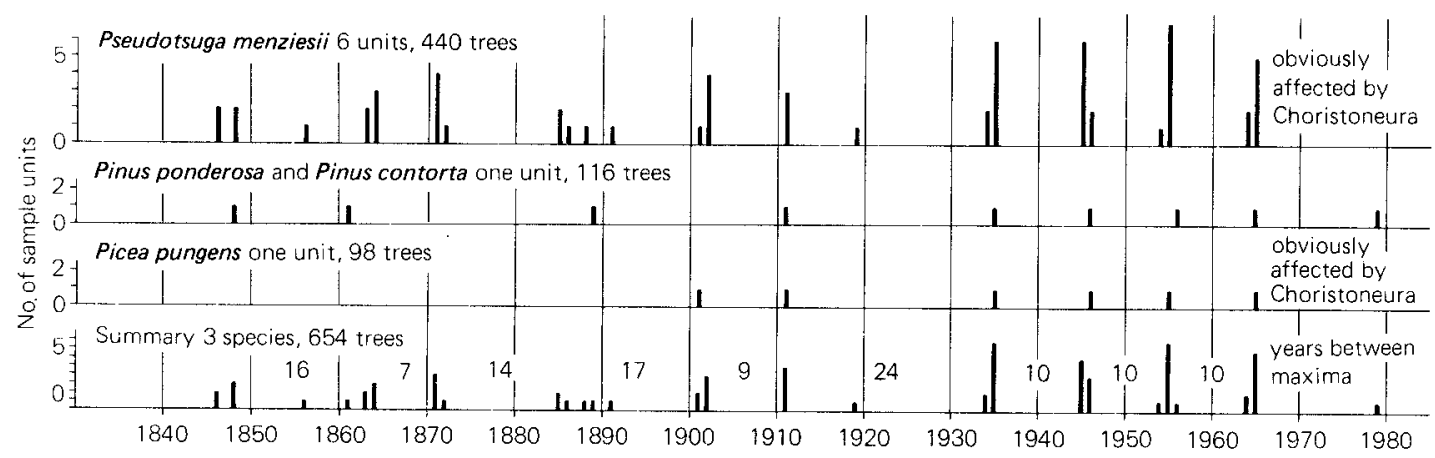

Fig. 6. As Fig. 5 but for three species from the area of Nederland, Boulder, Front Range, Colorado for the period 1840-1985. The diagram integrates the units of young and old trees ( $<80$ and $>80$ years old) from

low and medium elevations (2000-2300 $\mathrm{m}$ and $2500-2600 \mathrm{~m}$ ) and dry and moist sites. For this period, a periodicity of $7-24$ years is discernible 


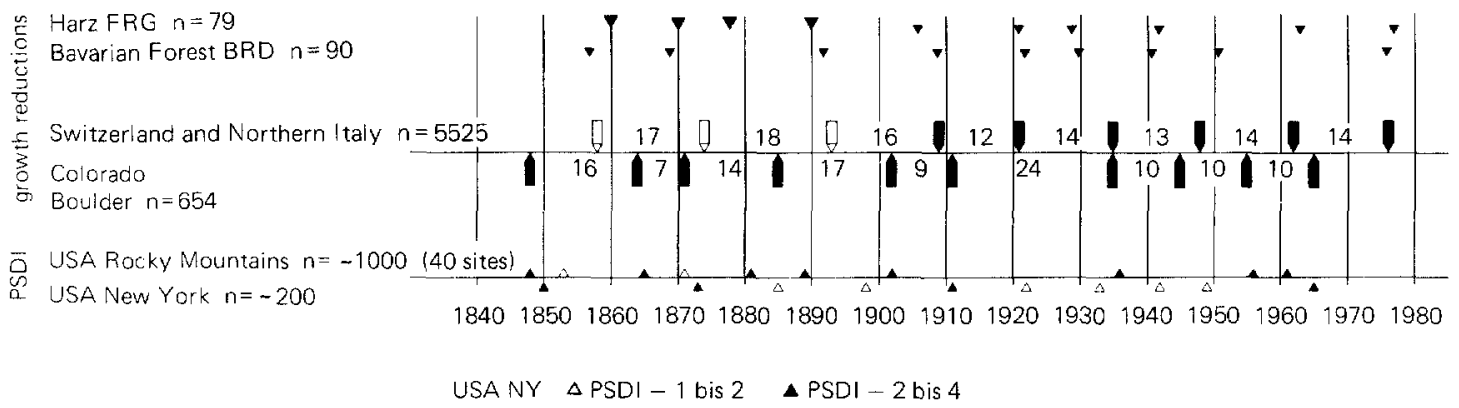

Fig. 7. Maximum frequencies of culmination points of reduction phases in Switzerland and northern Italy (see Fig. 5) and Boulder, Colorado (see Fig. 6) (indicated by large arrows) in comparison with corresponding, less densely covered chronologies from Bavarian Forest and the Harz
(Worbes 1989) indicated by small triangles, and Palmer Drought Severity Indices for July in the Rocky Mountains (Stockton and Boggess 1979) and the Hudson Valley, New York, USA (Cook and Jacoby 1979)
Table 3. Period lengths of growth reduction periods (GRP) and Palmer Drought Severity Indices (PDSI) in Europe and North America

\begin{tabular}{llll}
\hline Region & $\begin{array}{l}\text { Time-span } \\
\text { covered }\end{array}$ & $\begin{array}{l}\text { Mean period } \\
\text { length (years) }\end{array}$ & $\begin{array}{l}\text { Variability } \\
\text { in years }\end{array}$ \\
\hline Harz, FRG & $1850-1986$ & 13.6 & GRP \\
Switzerland, N. Italy & $1858-1976$ & 14.5 & GRP \\
Bavarian Forest & $1852-1976$ & 14.2 & GRP \\
New York & $1850-1965$ & 12.8 & PSD \\
Colorado, Front Range & $1848-1965$ & 13.8 & GRP \\
Rocky Mountains & $1848-1961$ & 14.1 & PSDI \\
\hline
\end{tabular}

values is an expression of the intensity of an ecological event. Further, the intensity of the growth reduction must be taken into account; great reductions, i.e. above $70 \%$, occur relatively seldom, while reductions of $40 \%-50 \%$ are relatively frequent. The remarks in Table 2 refer to the latter, the culmination points for which fall in 1948, 1962, and 1976.

The intensity of the reduction phases in Switzerland varies greatly. Barely discernible effects ( $4 \%$ difference) occur as well as quite strong effects ( $45 \%$ difference), and regular oscillations over a period of 100 years contrast with irregular fluctuations (Table 2).

Differences between species vary from region to region. In the Liestal area, Switzerland, there are no discernible differences between the frequency distributions for spruce, fir, and beech. In the Valais, on the other hand, the general trend of each species is different, but in every case, decennial phases are more or less distinct from the general course of the curve. The only event affecting only one species is that of 1956, which influenced fir. The differences between sites are slight and have not been investigated in detail. Basically, the trees on all of the sites are capable of abrupt reductions. That means that the trees, both in their crowns and their root systems, are adapted to their sites. A deficiency in water balance results in a growth reduction just as much on moist sites as on dry ones.

The patterns of periodicity are geographically limited (Figs. 5-7), as was also shown by Meko et al. (1985) and Shiatov (1987). The Central European area [northern Italy, Switzerland, French Jura (Bert 1988), Vosges (Levy and
Becker 1987) and Baden-Württemberg (Avemark and Schöpfer 1988)] forms one unit (Fig. 5) and another is the Boulder area in the Front Range, Colorado (Fig. 6). Periods of growth reduction evident in the ring sequences of 90 firs from the Bavarian forest synchronize only partly with those from the Alps (Fig. 7): 1858, 1893, 1910, 1921, 1976.

Differences occur in the following periods

$\begin{array}{ll}\text { Bavarian forest } & \text { Alps } \\ 1869 & 1874 \\ 1930 & \text { None } \\ \text { None } & 1948 \\ \text { None } & 1962\end{array}$

Although the moist, high elevation sites in the spruce belt in the Harz Mountains (FRG) differ from those in Switzerland, culmination years there synchronize with those in the Alps in 1909, 1921, 1962, and 1976 (Worbes 1989).

The sites in the restricted area of the Front Range display relationships in the periods computed by means of the Palmer Drought Sensitivity Indices (PDSI) for July for the western states of the USA (Mitchell et al. 1979; Fig. 7). The phases around 1848, 1864, 1872, 1900, and 1935 are synchronous. All the other phases show displacements in time.

The PSDI for the state of New York display little similarity to those for Europe and none at all to the fluctuations in western America (Fig. 7). The phases of 1873, 1921, and 1948 are synchronous with those of Central Europe.

The mean periodicity over the past 140 years is fairly uniform in all areas, at 13-14 years. The lengths of the periods vary between 6 and 34 years (Table 3). In no case, however, are the phases stationary (Pilcher and Munro 1987).

The mean chronological distance between the initiation of the fluctuation periods (event years) between 1921 and 1974 is 13 years; and between the culmination points for the same period 14 years. On the basis of variance analysis applied to maximum densities of conifers from high elevations in Central Europe, the periodicity was computed at 14.3 years (Schönwiese 1988).

The oscillations with a mean wavelength of $13-14$ years can be largely explained by climate), for both the 
Table 4. An explanation of the oscillations in the frequency of growth reductions in trees of Central Europe

\begin{tabular}{|c|c|c|}
\hline Phase & Weather & Growth rings \\
\hline Rd 1892 & Dry Sp and Su 1992 and 1993 & More frequent Rd, culmination 1893 \\
\hline Re 1903 & $\begin{array}{l}\text { Moist sp till 1908; moist Su } 1896 \text { and } 1901,1902 \text {, } \\
\text { and dry Su } 1894,1895,1898,1899\end{array}$ & $\begin{array}{l}\text { Continuous Rc till } 1901 \text {; no effects of dry Su; } \\
\text { equalizing effect of moist Su }\end{array}$ \\
\hline Rd 1909 & Dry Su 1903 and 1905 & Continuous Rd till 1909; dry Su have negative effect \\
\hline Rd 1921 & Dry Sp 1918 and 1921 and dry Su 1918, 1919, 1921 & $\begin{array}{l}\text { Abrupt increase in Rd from } 1918-1921 \\
\text { Sp and Su drought has effect }\end{array}$ \\
\hline $\operatorname{Rc} 1932$ & $\begin{array}{l}\text { Moist Sp } 1912-1942 \text { excl. } 1918,1921,1929 \\
\text { normal to moist Su } 1922-1932\end{array}$ & Continuous Rc; dry Su 1928 and 1929 have no effect \\
\hline Rd 1935 & Dry Sp 1934, dry Su 1934,1935 & Abrupt increase; dry Sp and Su have an effect \\
\hline Rc 1940 & Normal sp 1935-1942, excl. dry 1938; moist Su 1938-1941 & Slight but incomplete Rc; probably Su too dry \\
\hline Rd 1962 & Dry Sp 1957-1960; moist Sp 1962-1975 & $\begin{array}{l}\text { Dry Sp 1953-1960 trigger Rd despite moist Su 1953-1960, } \\
\text { dry Su 1961, } 1962 \text { have negative effect }\end{array}$ \\
\hline $\operatorname{Rc} 1970$ & Moist Sp 1961-1974 excl. 1968; normal Su 1963-1976 & $\mathrm{Rc}$ due to normal to moist $\mathrm{Sp}$ and $\mathrm{Su}$ \\
\hline Rd 1976 & See Rc 1970 & Increase in Rd inexplicable; dry Sp 1976 has no negative effect \\
\hline
\end{tabular}

The Table is based on Figs. 5 and 8 and the indexed precipitation values from the meteorological stations at Zurich, Berne, and Geneva (Pfister and Kirchhofer 1984)

Phase: $R d$, reduction phase; $R c$, recovery phase; $S$, stagnation phase

Weather: $S p$, spring (March-May); $S u$, summer (June-August)

Growth rings: Characteristics in the phase diagram of the study area Krauchthal (Fig. 8) and the culmination maxima (Fig. 5)

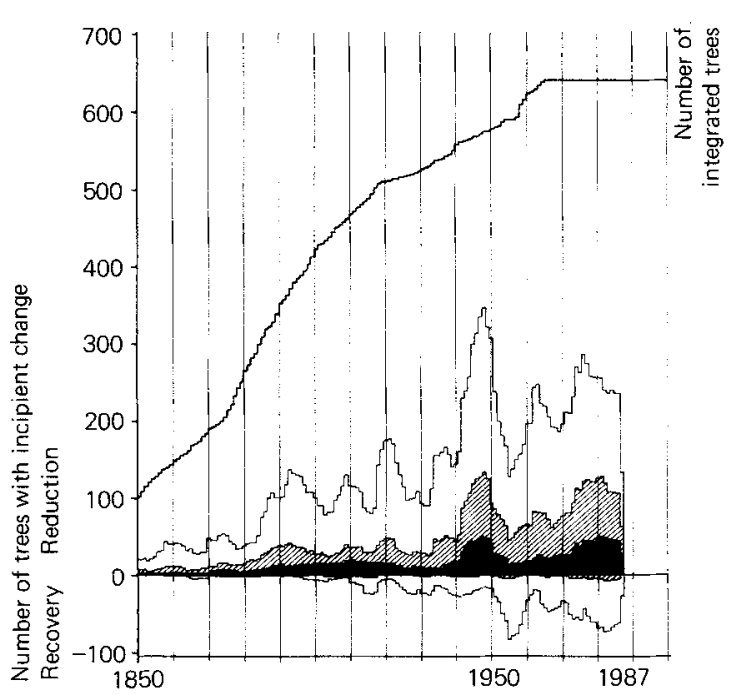

Fig. 8. Absolute frequency of growth reductions or recoveries in 640 forest trees of different species in Krauchthal near Bern, Switzerland. The oscillations are manifest. The number of trees with growth reduction increases with increasing age and number of trees integrated
USA (Stockton and Bogges 1979; Cook and Jacoby 1979) and Central Europe. Despite the similarity in quasi-periodicity on both continents, no direct relationship to cosmic, regular periodicities can be established, as the individual phases are asynchronous, at least as far as the continents are concerned (LaMarche and Fritts 1972). All studies so far conducted in Europe and the USA substantiate the dominant influence of drought stress. The PDSI for the month of July can be computed from ring width curves. Both in the dry, mountainous western states of the USA (Mitchell et al. 1979; Boggess 1979) and the Hudson Valley in the temperature zone in New York State, a quasi-periodicity has been found (Cook and Jacoby 1979). In the Front Range there is a relationship between the frequency of growth changes and periods with low annual precipitation. In Central Europe, this relationship is particularly close for the spring and summer months.

In the temperature area of Central Europe, the effects of climate on radial growth are much more complex in trees in dense stands than on solitary trees (Fritts 1976), as a climatic event affects the dynamics of a stand (conditions of competition), the various components of the stand react differently to a uniform climatic impact. Further, certain external factors seem only to exert an influence above a certain threshold, which varies from individual to individual. The following discussion seeks to explain the growth periodicity in Central Europe, in particular that of the trees in the Krauchthal (Bern, Switzerland), through climatic influences (Table 4, Figs. 5, 8). 
The relationships to precipitation are clear, though in individual cases some questions remain open. It has not yet been clarified why individual components of a stand often react differently. To explain this, intensive dendro-ecological studies on particular, strictly defined, uniform sites whose history of management is known are needed. Basic physiological data on the translocation of carbohydrates and their qualitative and quantitative effects on cambial activity after extreme climatic events are still to a large extent lacking.

In view of this paucity of data, it is hardly surprising that the negative or positive effects of harmful anthropogenic influences over large areas cannot be proven.

\section{Discussion}

Work on our own material and the findings of other authors show that growth ring sequences display rhythm. Only curves from trees periodically attacked by leaf-eating insects, e.g. Zeiraphera diniana (larch bud moth), with a 7to 9-year cycle (Schweingruber 1988) or Melolontha melolontha (cockchafer) with a 3- to 5-year cycle (Christensen in Schweingruber 1988) are clearly interpretable. Both in Central Europe and the USA, periodicities are of climatic origin. They can, however, only be recognized as such if a great deal of material from a climatically uniform area is available. There is little point in comparing and assessing all the cycles mentioned in the literature on dendrochronological studies, as the material is very heterogeneous. The major pitfalls, often overlooked in interpretation, are that:

1. The range of material is narrow, in extreme cases comprising one single tree (Papp 1983; Mori 1981; Attolini et al. 1988). Hundreds of ring sequences are needed to distinguish the influence of climate from the effects of stand dynamics.

2. The density of cover in mean curves varies. Particularly at the beginning they are computed from only a few individual curves. Most curves from fossil material contain certain sections which are only poorly covered (Pilcher and Munro 1987). Such weak sections should not be included in calculations, as they contain little information on overlying influences.

3. Different growth ring parameters are compared with each other, e.g. ring width, maximum, density, growth reduction, or PDSI.

4. Single curves from trees of different ages, from which age trend has not been eliminated, are used to construct mean curves. Consequently, mean curves contain individually governed long-term fluctuations.

5 . Where only a few curves from different species are integrated in a mean curve, the evidence obtained is presumably weak.

6 . Curves from trees from regions and sites with different climatic conditions are not a priori comparable (LaMarche and Fritts 1972; Budriunas and Bitvinskas 1987). For example, the material from the western USA primarily originates from dry sites (LaMarche and Fritts 1972; Mitchell et al. 1975), that from the boreal zone of Eurasia from moist and wet sites (Kairiukstis and Dubinskaite 1987), and that from Central Europe from medium sites.

7. The history of the stand influences the course of growth. The samples from Colorado were obtained from stands which suffered severely from over-exploitation between 1850 and 1920 and have since been unmanaged. Those from Switzerland, on the other hand, were collected from stands which have been managed for some 150 years. Differences may also arise due to the varying frequency of forest fires - every 2-6 years in semi-arid areas but only about every 300 years in boreal zones - and epidemic attack by insects, e.g. Lymanthria sp.

8. Only ring sequences from the same time are comparable, as the frequency of the periods is not stationary.

9. It is to be assumed that periodicities are read into the curves through statistical procedures. This is especially true for the 11- and 22-year sunspot cycles (Mitchell et al. 1979).

10. Prognoses based on a mean oscillation frequency are unreliable unless the maximum range of scatter over a defined unit of time is taken into account.

Acknowledgements. Our thanks go to all those former students at the Universities of Basel, Zurich and Florence who permitted us to evaluate the material used in their diploma theses and dissertations: $H$. Albrecht, Monika Beck, L. Bronzini, J. Hessel, D. Keller, F. Kienast, R. Kontic, K. Lange, M. Niederer, C. Nippel, S. Spang, Annemarie Spinnler, Barbara Steiner, and Amanda Winkler-Seifert. The Forest Office of Bolzano made the extensive material from their forest damage inventory available to us.

\section{References}

Attolini MR, Galli M, Nanni T, Ruggiero L, Zuanni F (1988). Preliminary observations of the fossil forest of Dunarobba (Italy) as a potential archive of paleoclimatic information. Dendrochronologia 6: $141-149$

Avemark W, Schöpfer W (1988) Abrupte Zuwachsänderungen von Fichten und Tannen. Forst Holz 43: 123-128

Bert GD (1988) Etude dendroécologique du dépérissement du sapin (Abies alba) dans le Jura. Memoire de Diplôme. University of Nancy

Cook ER, Jacoby GC (1979) Evidence for quasi-periodic July drought in the Hudson Valley, New York. Nature 282: 390-392

Fritts HC (1976) Tree rings and climate. Academic press, London, pp 567

Kairiukstis L, Dubinskaite J (1987) Modeling fluctuations of dendrochronological indices to predict eco-climatic background variability. Methods of dendrochronology. Int Inst Applied System Analysis, Warsaw, pp 143-162

Kienast F, Flühler H, Schweingruber FH (1981) Jahrringanalysen an Föhren (Pinus silvestris L.) an immissionsgefährdeten Waldbeständen des unteren Wallis (Saxon, Schweiz) Eidg Anst Forstl Versuchswes Mitt 57: 415-432

Kontic R, Niederer M, Nippel C-A, Winkler-Seifert A (1986) Jahrringanalysen an Nadelbäumen zur Darstellung und Interpretation von Waldschäden (Wallis, Schweiz). Eidg Anst Forstl Versuchswes, Berichte 283: pp 46

LaMarche VC, Fritts HC (1972) Tree-rings and sunspot numbers. TreeRing Bull 32: 19-33

Levy G, Becker M (1988) A propos du dépérissement des forêts: climat, silviculture et vitalité de la sapinière vosgienne. Rev For Fr 40 : $403-416$

Meko DM, Stockton CW, Blasing TJ (1985) Periodicity in tree rings from the corn Belt. Science 229: $381-384$ 
Mitchell JM, Stockton CW, Meko CW (1979) Evidence of a 22-year rhythm of drought in the western United States related to the Hale Solar Cycle since the 17th century. In: McCormac BM, Seliga TA (eds) Solar-terrestrial influences on weather and climate. Reidel, Dordrecht, pp 125-143

Mori Y (1981) Evidence of an 11-year periodicity in tree ring series from Formosa related to the sunspot cycle. J Climatol 1: $345-353$

Papp Z (1983) Investigations on the climatic effects of great volcanic eruptions by the method of tree-ring analysis. Bull Volcanol 42 : $89-102$

Pfister C (1984) Saisonale Niederschlagsverhältnisse. In: Kirchhofer W, (ed) Klimaatlas der Schweiz. Bundesamt für Landestopographie, Wabern, Bern

Pilcher JR, Munro MAR (1987) Long composite chronologies as indicators of background variations in tree growth. In: Kairiukstis L, Kairiukstis L, Bednarz Z, Feliksik E (eds) Methods of dendrochronology. Int Inst Applied System Analysis, Warsaw, pp 117-123

Schönwiese C-D (1988) Die Spätholzdichte europäischer Nadelbäume als möglicher Frühindikator grossräumiger Waldschäden. Umwelt- forschungsplan des Bundesamtes für Umwelt, Naturschutz und Reaktorsicherheit. FE-Vorhaben 10603046/39. S. 106

Schweingruber FH, Albrecht H, Beck M, Heesel J, Joos K, Keller D, Kontic R, Lange K, Niederer M, Nippel C, Spang S, Spinnler A, Steiner B, Winkler-Seifert A (1986) Abrupte Zuwachsschwankungen in Jahrringabfolgen als ökologische Indikatoren. Dendrochronologia 4: $125-183$

Schweingruber FH (1988) Tree rings. Basics and applications of dendrochronology Kluwer, Dordrecht, Boston, London, p 276

Shiatov SG (1987) Predicting future growth trends from tree-ring series. In Kairiukstis L, Kairiukstis L, Bednarz Z, Feliksik E, (eds) Methods of dendrochronology. Int Inst Applied System Analysis, Warsaw, pp 137-141

Stockton CW, Boggess WR (1979) Augmentation of hydrological records using tree rings. Proc Engineering Found Conf, Pacific Grove, pp 239-265

Walter H, Lieth H $(1960,1964,1967)$ Klimadiagramm-Weltatlas. 3 Bände. Fischer, Jena

Worbes M (1989) Abrupte Zuwachsreduktionen an Fichten aus dem Harz. Forst Holz 44: 254-259 